УДК 624.131

\title{
ТИПИЗАЦИЯ ИНЖЕНЕРНО-ГЕОЛОГИЧЕСКИХ УСЛОВИЙ ТЕРРИТОРИИ ТРАССЫ ПРОЕКТИРУЕМОЙ ЖЕЛЕЗНОЙ ДОРОГИ ЭЛЕГЕСТ-КЫЗЫЛ-КУРАГИНО
}

\author{
Строкова Людмила Александровна', \\ sla@tpu.ru \\ Надеждина Юлия Юрьевна, \\ levak.yuliya@mail.ru \\ 1 Национальный исследовательский Томский политехнический университет, \\ Россия, 634050, г. Томск, пр. Ленина, 30.
}

\begin{abstract}
Актуальность исследования обусловлена разработкой проекта первой железной дороги в Тыве, которая должна связать Тыву с Красноярским краем. Трасса планируется в сложных инженерно-геологических условиях. В статье представлена типизация инженерно-геологических условий территории трассы. Инженерно-геологическая оценка территории необходима для того, чтобы поддержать процесс принятия решений по размещению сооружений, а также чтобы строительство объектов осуществлялось с меньшим отрицательным воздействием на окружающую среду, сопровождалось снижением опасности и ущерба как для строительства, так и в целом для общества и экономики.

Целью данного исследования является типологическое и региональное инженерно-геологическое районирование территории с учетом последних работ по изучению инженерно-геологических условий трассы.

объектом исследования является геологическая среда района проектируемой трассы Кызыл-Курагино. Рассмотрены основные природные компоненты, влияющие на формирование инженерно-геологических условий: геоморфологические и тектонические условия; литологический состав; физико-механические свойства пород, гидрологические, гидрогеологические и мерзлотные условия района, экзогенные и эндогенные геологические процессы.

Методы: краткий обзор литературных источников и анализ информации, полученной из фондов изыскательских организаций, определение признаков и методики районирования. Все инфрормационные слои о природной среде обрабатьвались, затем объединялись для получения единой инженерно-геологической карты с характеристикой районов.

Результаты. Выбраны классификационные признаки геологической среды, и составлена карта районирования инженерногеологических условий участка трассы, дана характеристика выделенных таксонов.

Выводы. Дана характеристика основных факторов региональной инженерно-геологической обстановки, и приведены результаты районирования на основе принципа формационного анализа и типизации инженерно-геологических условий территории.
\end{abstract}

\section{Ключевые слова:}

Инженерно-геологические условия, региональные фракторы, железная дорога, районирование, геологические процессы.

\section{Введение}

Строительство железной дороги КурагиноКызыл-Элегест будет способствовать развитию производственного комплекса и экономики Тывы. На пути железной дороги (длиной в 412 км: 124 км по Тыве и 288 км по Красноярскому краю) - хребты Западного Саяна, через которые необходимо пройти восемь тоннелей и соорудить 127 мостов (в отдельных местах высота опор будет достигать 90 м). Дорога потребует сооружения 1087 водопропускных труб, протяженностью более 25 км и строительства более 600 км автодорожных подъездов и временных автодорог. Строительство будет осуществляться в крайне сложных инженерно-геологических условиях.

Слабая изученность инженерно-геологических условий (ИГУ) региона из-за труднодоступности местности, суровости климата повышает значимость инженерно-геологического типологического районирования этой территории. Технология его выполнения, включающая следующий ряд «последовательных операций: определение границы территории (объекта); изучение объекта; выбор классификационных признаков типизации; их ранжирование по степени значимости; разделение рассматриваемой территории (объекта) по принятым признакам; построение итоговой карты районирования территории», подробно изложена в работах [1-9]. Этот метод позволяет упорядочить имеющиеся знания об инженерногеологических особенностях территории, поэтому давно и широко используется в мире [10-18].

Изучение основных закономерностей формирования, пространственного распределения и изменения самих инженерно-геологических условий тесно связано с изучением инженерно-геологических структур, под которыми понимаются «объемные природные образования, различающиеся по признакам, наиболее значимым с точки зрения инженерно-строительной деятельности» $[19,20]$.

Краткая характеристика инженерно-геологических структур России и, в частности, Алтае-Саянской горной области приведена в монографии [21]. В соответствии с последней классификацией инженерногеологических структур Земли [22], по региональногеологическому ряду Алтае-Саянская область относится к континентальному древнему орогену. По зонально-климатическому ряду область относится к субаэральной структуре 1-го порядка, внутри которой выделяются структуры 2-го порядка по зонам сплошного, прерывистого, островного распространения вечной мерзлоты и ее отсутствия.

Освоение территории требует более детальной инженерно-геологической характеристики района. 
Выполнение типизации ИГУ поможет обоснованно выбрать наиболее оптимальный вариант трассы. Для этого необходимо рассмотреть основные особенности геологической среды, влияющие на планирование и развитие землепользования: сейсмотектонику; литологию; топографию; гидрологию, гидрогеологию и вечную мерзлоту.

Целью данного исследования является типизация инженерно-геологических особенностей района с учетом последних работ по изучению ИГУ трассы.

Исследование проведено весной 2019 г. в отделении геологии ТПУ. Оно включало анализ литературных и фондовых материалов, полученных при инженерно-геологических изысканиях отдельных участков трассы, выполненных различными проектными организациями в 2009-2019 гг.; их обобщение и районирование.

\section{Характеристика инженерно-геологических условий}

Основные особенности любой территории обусловлены совокупностью геологических процессов, реализованных в ходе истории геологического развития территории, поэтому одним из основных признаков типизации является тектоническое строение территории.

В тектоническом отношении зона предполагаемой трассы находится в центральной части АлтаеСаянской области, относится к типу мозаичноблоковых и представляет из себя коллаж разновозрастных и разнотипных сооружений [23, 24]:

- палеомикроконтинентов - добайкальских массивов на юго-востоке (Сангиленская глыба) и островодужно-офиолитовых поясов (Куртушибинский, Борусский, Западно-Тывинский, СевероСаянский);

- пассивных континентальных окраин палеокеанов: салаирских складчатых систем - на северо-востоке (Восточносаянская), востоке (ВосточноТывинская), на юго-востоке (Верхне-Енисейская); каледонских - на западе и юго-западе (Западносаянская-Тывинская система);

- ареалов проявления коллизионного интрузивного магматизма;

- наложенные структуры позднепалеозойской, мезозойской активизации и кайнозойского рифтогенеза, выраженные морфологически в виде впадин, прогибов и линейных зон деформаций, линейных ареалов малых интрузий, роев даек и излияний базальтов.

Из Восточносаянской системы в северной части площади находится Казым-Кизирский синклинорий Сисимо-Казырской салаирской складчатой зоны. В ее строении принимают участие отложения позднего рифея, венда и кембрия, нарушенные многочисленными разломами и интрузиями разного возраста. Широко развита орогенная моласса, представленная конгломератами, гравелитами, песчаниками с редким присутствием вулканогенных пород, в основном туфов, от основного до кислого состава. Мощность комплекса более $3000 \mathrm{~m}$.
Восточно-Тывинская салаирская система располагается в восточной части площади, представлена Систигхемским синклинорием - орогенной структурой длительного развития (€2-С). Северный борт синклинория срезается Кандатским разломом, а южный - ХемчикскоАзасским. Западная граница почти нацело перекрывается зоной Куртушибинского разлома. На завершающей стадии каледонской складчатости здесь образовался крупный Хемчикско-Систигхемский прогиб. Ширина прогиба меняется от 60 км в юго-западной части до 30 км в северо-восточной. Прогиб выполнен терригенно-карбонатной флишоидной и карбонатнотерригенной молассовой формациями ордовика и силура. Мощность флишоидного комплекса непостоянна от 5500 м на северо-востоке до 8000 м на югозападе [23, 24].

Верхне-Енисейская салаирская складчатая система включает в себя Восточно-Таннуольский антиклинорий и Ондумский синклинорий.

Каледонская структура Западного Саяна имеет покровно-складчатое строение с элементами складчато-глыбовой. Основные тектонические элементы отделены друг от друга разломами как глубинного, так и регионального характера. Как складчатое сооружение Западный Саян ограничен зонами глубинных разломов: с севера - Саяно-Минусинским и Кандатским, с юго-востока - Куртушибинским. В этих зонах развиты гипербазиты и зеленокаменоизмененные осадочно-вулканогенные породы верхнего рифея, венда, нижнего и среднего кембрия и силура. В совокупности они образуют крупные офиолитовые аллохтоны: Северо-Саянский, Борусский и Куртушибинский. Офиолитовые аллохтоны представляют собой ассоциацию альпинотипных гипербазитов и интенсивно деформированных вулканитов, мощность их более 6-7 км, возраст не выходит за пределы позднего рифея и самого начала раннего кембрия.

В Западносаянских каледонидах выделяются две зоны: Северо-Саянская и Центрально-Западносаянская. Северо-Саянская зона сложена породами от нижнего до среднего кембрия. Границы зоны тектонические. Морфологически это крупный по размерам прогиб. Как горная система Северо-Саянская зона продолжает испытывать поднятие и в настоящее время, находясь в зоне сейсмически активного СаяноМинусинского разлома. Центрально-Западносаянская зона составляет основную, большую, часть Западного Саяна. Она ограничена разломами: с севера - СаяноМинусинским, с юго-востока - Куртушибинским. В северо-западной части Центрально-Западносаянская зона разделяется Борусским офиолитовым аллохтоном на две неравные части: меньшая соответствует Джебашскому антиклинорию, большая - ЦентральноЗападносаянскому синклинорию. В их строении участвуют вулканогенно-осадочные отложения мощностью до 30 км, по возрасту от венда до позднего силура, разбитые на блоки. Центральная часть Западного Саяна насыщена многочисленными разновеликими массивами гранитоидов не древнее раннего девона [24]. 
Одними из главных структур Алтае-Саянской складчатой области являются посторогенные струкmуры, сформированные в режиме континентального рифтогенеза, которые представлены в пределах Красноярского края палеозойскими впадинами: ЮжноМинусинской и Усинской. Мощность рыхлых отложений более 4000 м. В пределах Тывы структуры палеозойской активизации включают ЦентральноТывинский рифтогенный прогиб, Хемчикский, Тоджинский, Турано-Уюкский грабены, Кызыльскую, Элегетскую и Онкажинскую наложенные мульды. К наложенным структурам мезозойской активизации относят Улуг-Хемскую и Шагонарскую угленосные впадины с мощностью рыхлых отложений более 2500 м, к структурам кайнозойской активизации Хемчикскую, Чаданскую и Буренскую впадины с мощностью рыхлых отложений от 150 до 400 м [23].

Большую роль в разграничении структур играют глубинные (мантийные) и региональные разломы.

В геоморфологическом отношении территория трассы характеризуется большим разнообразием. Здесь распространены высокогорные (более 2000 м), среднегорные хребты с абсолютными отметками $1000 \ldots 2000$ м, низкогорные - до 1000 м, а также аккумулятивные и денудационные равнины меж- и внутригорных впадин с высотами поверхности $300 \ldots 700 \mathrm{M}$.

Геокриологические условия. Формирование криолитозоны связано с образованием высокоподнятых гор. Характерные для настоящего времени природные условия начали складываться в палеогене и окончательно сформировались в четвертичный период.

В Саянах общая площадь оледенения составляет около 33 км², преобладают каровые ледники небольшого размера. На Западном Саяне обнаружено 52 маленьких ледника общей площадью чуть больше 2 $\mathrm{kм}^{2}$, а в пределах Восточного Саяна - 107 ледников $\left(30 \mathrm{~km}^{2}\right)$. Большое значение в существовании ледников имеет метелевый перенос снега. Ледники Саян мало изучены. Заключения об уменьшении размеров ледников ученые делают, принимая во внимание положение конечных морен, зафиксированных экспедициями 1960-х гг. [21].

Важной особенностью этой территории является широкое и чрезвычайно пестрое распространение сезонной мерзлоты и многолетнемерзлых пород (ММП).

Пояс сплошного распространения ММП представлен в наиболее приподнятых горных массивах либо отдельных вершинах хребтов на высотах 2000 м и выше. На участках сплошного распространения ММП занимают 90 \% площади и фиксируются на большинстве склонов, в том числе и южной экспозиции. Данных о температуре и мощности мерзлых толщ для наибольших высот Саяно-Алтайской области нет [21]. Однако по аналогии с Горным Алтаем предполагаемая мощность мерзлой толщи горных пород высокогорий Тывы может быть 400 м и достигать 1 км. На карте геокриологического районирования СССР показана мощность ММП 200-400 м со среднегодовой температурой от -3 до $-5^{\circ} \mathrm{C}[25]$.
Пояс прерывистого распространения ММП представлен в интервале высот 1500-2000 м. В этом же геокриологическом поясе находятся хребты Западный и Восточный Танну-Ола, что объясняется их расположением в окружении степей и связанным с этим недостаточным увлажнением грунтов. Встречаются участки прерывистой мерзлоты в Тоджинской котловине. В этом поясе ММП развиты не только на дне депрессий и в привершинных частях склонов северной экспозиции, но и у их подножий. Мощность мерзлой толщи горных пород изменяется до 100 м, реже до 300 м со среднегодовой температурой от 0 до $-2{ }^{\circ} \mathrm{C}$. Глубина сезонного протаивания грунтов составляет $0,4 \ldots 0,5$ м в торфяниках, $0,3 \ldots 2,5$ м в суглинках, и $1 . . .3,2$ м в супесях.

Островное распространение ММП представлено широкой полосой в нижней части хребтов Восточного Танну-Ола, хребта Обручева, почти полностью охватывает Тоджинскую и Туран-Уюкскую впадины и в незначительной мере - Тывинскую депрессию. В горах островная мерзлота развита в интервале высот $1000 \ldots 1500$ м в зависимости от экспозиции склонов, литологического состава грунтов, их влажности, почвенно-растительного покрова. В котловинах мерзлота обнаруживается на высоте 500...900 м. Мощность ММП незначительная, в горах $-10 \ldots 30$ м, на дне котловин - 5...15 м, редко 30 м. Средняя многолетняя температура колеблется от 0 до $-1,5^{\circ} \mathrm{C}$.

Пояс редкоостровной многолетней мерзлоты представлен в степных и полупустынных ландшафтах Тывинской котловины, на склонах окружающих их хребтов в интервале высот $600 \ldots 1200$ м. Среди талых пород в пониженных частях котловин встречаются редкие острова многолетнемерзлых пород и перелетки.

Пояс сезонного промерзания пород представлен в ландшафтах Южно-Минусинской котловины.

Характер ММП и сезонной мерзлоты в разных ландшафтно-геоморфологических условиях региона определяет развитие криогенных процессов. На плоских водораздельных поверхностях и склонах высокогорий мерзлотные процессы представлены нагорными террасами, курумами, криоструктурными и солифлюкционными образованиями [25]. В днищах межгорных котловин широко развиты морозобойные трещины, бугры пучения, наледи и термокарстовые просадки и наледеобразование. В условиях альпинотипного рельефа активно проявляются нивальные и эрозионно-денудационные процессы, обуславливающие широкое распространение обвалов, осыпей, подвижных курумов, донной эрозии, селей, снежных лавин (рис. 1).

В гидрогеологическом отношении территория трассы располагается в границах единой гидрогеологической Алтае-Саянской складчатой области, представляющей собой сложную систему гидрогеологических массивов (Восточно-Саянский, Западносаянский и Восточно-Тывинский) и межгорных бассейнов. В пределах последних выделены Южно-Минусинский, Усинский, Улуг-Хемский адартезианские бассейны с различной обводненностью, минерализацией $[23,24]$. 


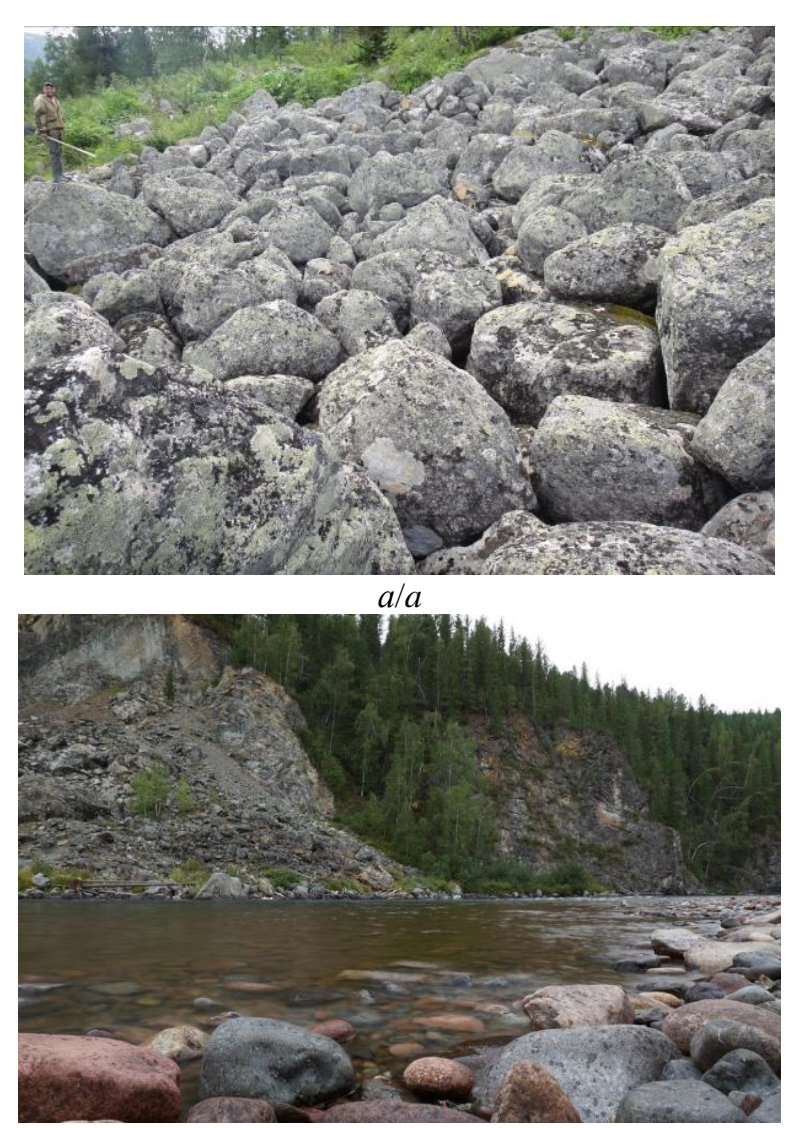

$6 / b$

Pис. 1. а) нарушение лишайникового покрова, свидетельствующее о подвижности курума (хр. Чатырба-Тайга); б) осыпь на р. Ус (фото В. Сергеeва)

Fig. 1. a) violation of the lichen cover, indicating the mobility of stone run (ridge Chatyrba-Tayga); b) scree on the river Us (photo by V. Sergeev)

Гидрогеологические массивы, сложенные осадочными и метаморфическими породами докайнозойского возраста и интрузивными породами, содержат трещинно-поровые воды зоны трещиноватости скальных пород, трещинно-карстовые воды в районах развития карбонатных разностей и трещинножильные воды зон тектонических нарушений.

Наиболее развиты по площади воды зоны приповерхностной трещиноватости, часто имеющей мощность не более 100 м, редко 150 м и более. Глубина залегания трещинных вод до $50 \ldots 60$ м. В связи с различной степенью трещиноватости пород воды распределены неравномерно как по площади, так и в разрезе. Преобладающая водообильность пород невелика: дебиты родников $0,1 \ldots 3$ л/с, лишь иногда достигают 10 л/с.

Трещинно-жильные воды, приуроченные к зонам тектонических нарушений, часто выходят на поверхность в виде восходящих родников с дебитом до $5 . .10$ л/с, а дебиты скважин достигает 50 л/с. От других типов вод отличаются минерализацией и солевым составом: встречаются гидрокарбонатные натриевокальциевые и гидрокарбонатные натриевые, сульфатные натриевые, азотные кремнистые, сероводородные воды. Обычно это холодные, иногда термальные воды, пресные, солоноватые с минерализацией до 3 г/л, реже соленые. В них чаще, чем в других типах вод, встречаются агрессивные по отношению к бетону и металлу.

Криогидрогеологические массивы характеризуются широким, практически сплошным, развитием многолетнемёрзлых пород, мощность которых, как правило, превышает мощность зоны трещиноватости. На территориях с прерывистым развитием многолетнемёрзлых горных пород могут присутствовать участки как гидрогеологических, так и криогидрогеологических массивов со всеми присущими им особенностями.

Артезианские бассейны приурочены к межгорным впадинам, выполненным рыхлыми кайнозойскими отложениями, в меньшей мере формациями мезозоя. Подземные воды развиты в породах всего чехла каждого из бассейнов. Основные запасы подземных вод сосредоточены в наиболее древних водоносных комплексах, выполняющих впадину. В строении артезианских бассейнов участвуют также воды зон разломов, а в бассейнах со сплошным развитием - многолетнемерзлых пород.

В долинах крупных рек водоносные горизонты мощностью 2...7 м приурочены к аллювиальным пескам и галечникам, глубина их залегания изменяется от $0,5 \ldots 8$ м на поймах до $5 \ldots 12$ м на низких террасах и до 15 м на средних и высоких террасах. Годовая амплитуда уровня грунтовых вод достигает $1 \ldots 2,5$ м, наиболее высокое его положение отмечается в конце мая - начале июня. Удельные дебиты скважин в песчано-гравийно-галечниковых отложениях пойм и низких террас близки к 1,5 л/с.

Подземные воды озёрно-аллювиальных отложений приурочены к песчано-гравийно-галечниковым пачкам, залегающим на глубине $10 \ldots 25$ м, или к прослойкам и линзам песков, залегающим среди водоупорных пород на различной глубине. Часто они имеют спорадический характер, во многих случаях обводнены незначительно. Дебиты скважин не превышают долей литра в секунду.

Подземные воды аллювиально-пролювиальных образований, слагающих предгорные шлейфы и конусы выноса, встречаются на глубине 5...50 м. Водоносность пород крайне неравномерна - преобладают слабоводоносные породы, но в отдельных случаях отмечаются выходы родников с дебитами до 5 л/с [23, 24].

Важные особенности подземных вод региона изучены недостаточно и неравномерно. Особенно плохо изучена агрессивность подземных вод. Имеются указания на изменения агрессивности грунтовых вод и верховодки в зависимости от сезона. Подземные воды могут значительно осложнять проходку горных выработок и устройство выемок.

\section{Методика и результаты исследований}

Наше исследование включало анализ литературных и фондовых материалов, установление принципов и методики районирования, картографирование. Методические основы выполненного районирования 
основываются на схемах, разработанных И.В. Поповым, Г.А. Голодковской, В.Т. Трофимовым [22], Сулакшиной Г.А., Емельяновой Т.Я, Строковой Л.А. [23-29], в которых учитываются как региональные- геологические, так и зонально-климатические особенности инженерно-геологических условий. Создание карты проводилось в следующей последовательности (рис. 2.)

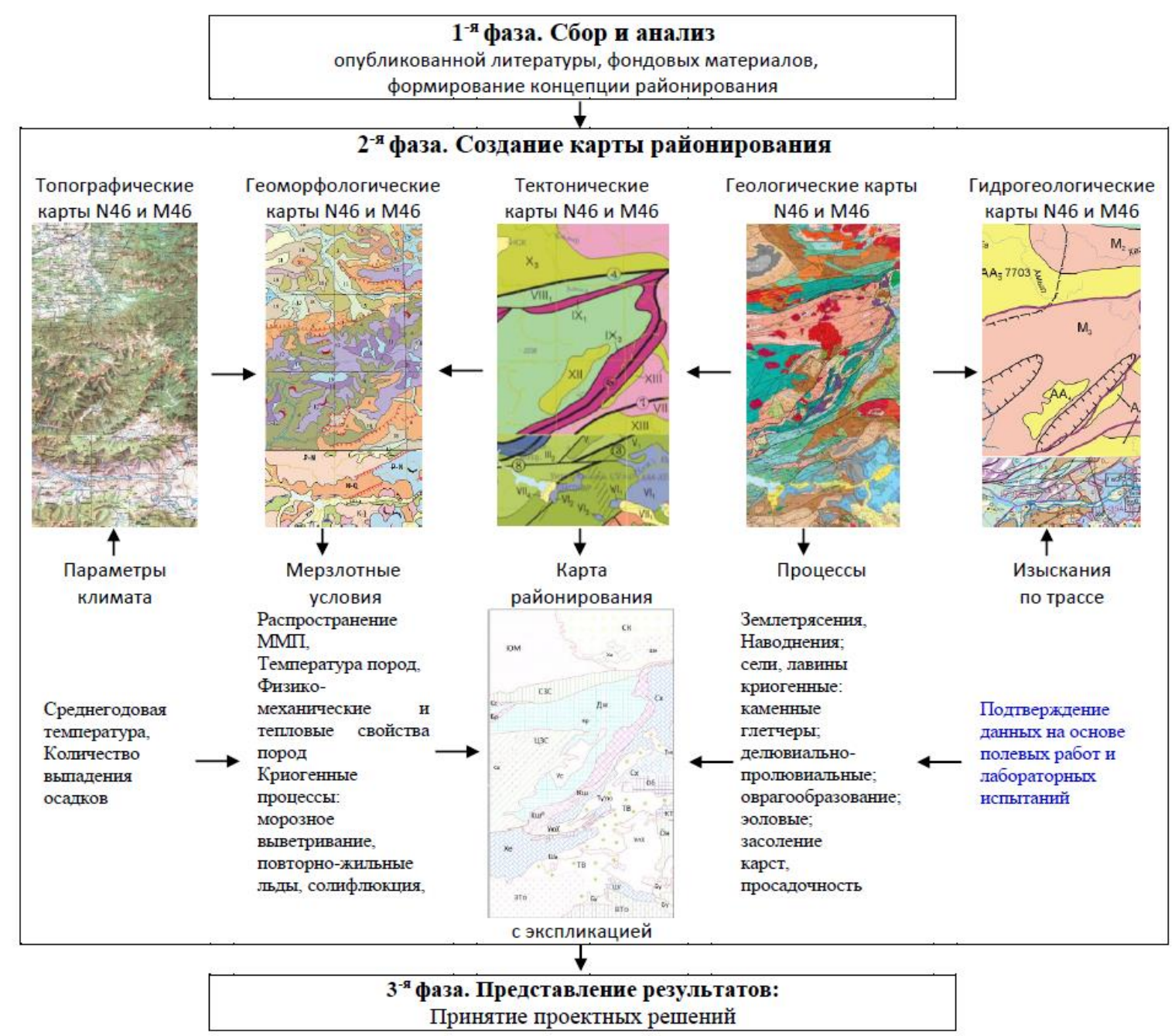

Pис. 2. Схема разработки карты

Fig. 2. Flowchart of mapping

Вначале были собраны и проанализировны имеющиеся опубликованные и фондовые материалы и разработана концепция районирования. В качестве источников информации для составления карты отобраны данные: региональных геологических исследований района масштаба, результатов бурения и опробования 2418 инженерно-геологических скважин в 2012-2017 гг. Состав и физико-механические свойства изучены по 5965 пробам грунтов и 1027 образцов скальных пород, в их определении непосредственно участвовала Ю.Ю. Надеждина. При разработке карты районирования в AutoCAD были созданы следующие информационные слои: «Рельеф» с горизонталями 1000, 1500, 2000, 2500 м; «Мерзлотные границы» с зонами сплошного, перерывистого, остовного распространения мерзлоты; «Реки и водоемы», «Геология» и «Тектоника» - растры из $[30,31]$ «Процессы гравитационные» - места курумов, оврагов; «Заболачивание» - оцифрованы с топоосновы;
«Селевая активность», «Лавинная опасность», «Интенсивность землетрясений», «Карст», «Оползневая опасность», «Интенсивность неотектонических движений», «Просадочность», последние слои - растры из [32].

Выделение единиц настоящего районирования проводилось по генетико-морфологическому типу, смешанному (типологическому и региональному) виду районирования (по систематике В.Т. Трофимова, 1979). Вначале при типологическом районировании выделены структуры I-го порядка (мегаструктуры) по площади распространения ММП и структуры II-го порядка - мезоструктуры (по геоструктурному признаку - складчатые системы/впадины). Далее районирование осуществялось по региональному (индивидуальному) виду с учетом основных регионально-геологических и зонально-климатических условий. В пределах структур II-го порядка выделены 26 структур III-го порядка (микроструктуры). 
Главным фактором, контролирующим сложность строительного освоения, распространение геологических процессов, являются тектоническое строение территории и неотектоническая активность, именно они служат тем фокусом, в котором отражаются инженерно-геологические особенности территории, возникающие в процессе «геологической» жизни, в частности рельеф, литологический состав пород, гидрогеологические и мерзлотные условия. Именно по этому признаку проведены границы структур III-го порядка.

Все информационные слои обрабатывались в AutoCAD для получения единой карты инженерногеологического районирования (рис. 3).

Конечные таксоны по регионально-геологическим и зонально-климатическим условиям были обособлены путем наложения друг на друга перечисленных информационных слоев. Характеристика таксонов приведена в табл. 1.

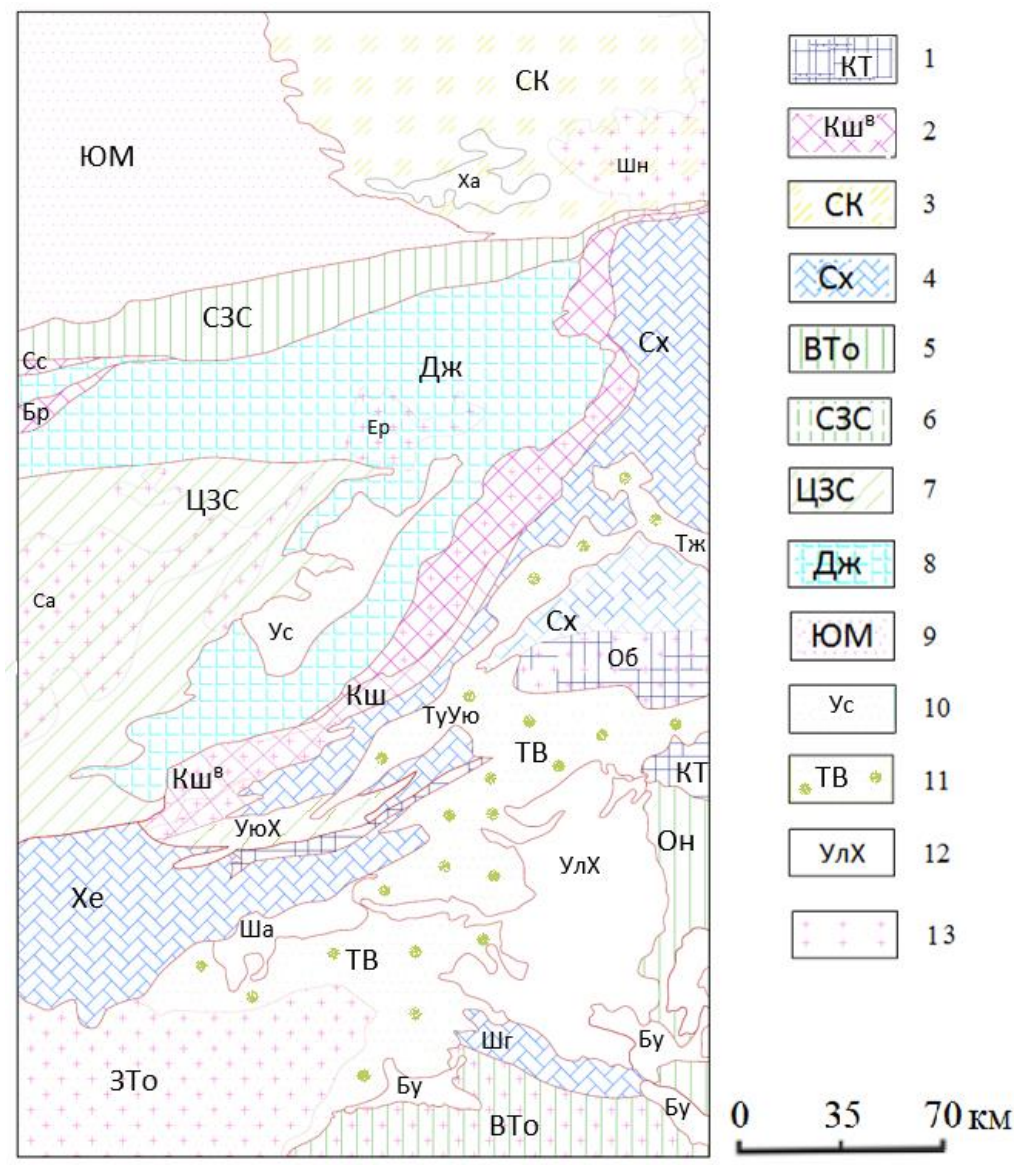

Рис. 3. Карта типологического инженерно-геологического районирования по регионально-геологическим и зональноклиматическим факторам: 1 - добайкальские массивы (V-C1 фундамент Хемчикско-Сыстыгхемского прогиба - КТ); 2 - V-С1 остороводужно-офиолитовые пояса (Куртушибинкий - Кш, Северосаянский - Сс, Борусский - Бр); 3-8 складчатые системы салаирид: 3 - Сисимо-Казырская - СК, 4 - ХемчикскоСыстыгхемская - Хе-Сх, 5 - Таннуольско-Хамсаринская, в т. ч. подзоны Восточно-Таннуольская - ВТо, Ондумская - Он; и каледонид: 6 - Северо-Западносаянская - СЗС, 7 - Центрально-Западносаянская - ЦЗС, 8 Джебашская - Дж; 9-12 - наложенные структуры эпох активизачии: позднепалеозойские (9 - Южно-

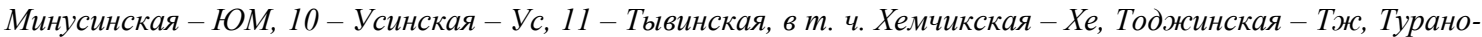
Уюкская - ТуУю, Шугурская - Шг); 12 - мезозойские (Улугхемская - УлХ, Шагонарская - Ша) и кайнозойские (Буренская - Бу) зоны. 13 - высокогорные районы (более 2000 м). Остальные сокращения названий приведены в табл. 1

Fig. 3. Map of typological engineering-geological zoning by regional-geological and zonal-climatic factors: $1-V-C 1$ foundation Khemchik-Systygkhem forearc trough; $2-V$-Cl ophiolite Kurtushiba - Ku, North-Sayan - Cc, BoruskiБр; 3-8-fold system salaire sediments: 3 - Sisimo-Kozyrska - CK, 4 - Khemchik-Systygkhem - Xe-Cx, 5 Tannuola-Khamsara island arc zone, subzone: BTo - Tannuola, OH - Ondum; and caledonides: 6 - North western Sayan-C3C, 7 - Central Western Sayan area - ЦЗС, 8 - Dzhebashskaya - Дж; 9-12 - imposed structure of epochs of activation: the late paleozoic (9 - South-Minusinski, 10 - Usinski - Yc, 11 - Tyvinian, including Khemchikskaya, Todzhinskaya, Turano-Uyukskaya - ТуУю, Shugurskaya-Шг); 12 - mesozoic (Ulughemksky - УлX, Shagonarskaya - Wa) and Cenozoic (Burenskaya - Бy) zones. 13 - high-altitude areas (more than $2000 \mathrm{~m}$ ). The remaining abbreviations are given in table 1 
Таблица 1. Экспликащия к карте районирования

Table 1. Explication to the zoning map

\begin{tabular}{|c|c|c|c|c|c|c|c|}
\hline \multicolumn{2}{|c|}{\begin{tabular}{|c|} 
Типологические инженерно- \\
геологические структуры \\
Typological engineering-geological structures
\end{tabular}} & \multicolumn{2}{|c|}{\begin{tabular}{|c|} 
Региональные инженерно- \\
геологические структуры \\
Regional engineering-geological structure
\end{tabular}} & \multicolumn{4}{|c|}{$\begin{array}{l}\text { Характеристика таксонов } \\
\text { Characteristics of taxa }\end{array}$} \\
\hline $\begin{array}{l}\text { Мегаструктуры } \\
\text { Megastructures }\end{array}$ & $\begin{array}{l}\text { Мезоструктуры } \\
\text { Mesostructures }\end{array}$ & $\begin{array}{l}\text { Мезоструктуры } \\
\text { Mesostructures }\end{array}$ & $\begin{array}{c}\text { Микроструктуры } \\
\text { Microstructures }\end{array}$ & $\begin{array}{c}\text { Абсолютные } \\
\text { отметки, м } \\
\text { Altitude, m }\end{array}$ & $\begin{array}{c}\text { Количество } \\
\text { осадков, } \\
\text { мм/год } \\
\text { Precipitation } \\
\text { mm/year }\end{array}$ & $\begin{array}{l}\text { Возраст и состав горных пород } \\
\text { Rock age and structure }\end{array}$ & $\begin{array}{l}\text { Геологические процессы } \\
\text { Geological processes }\end{array}$ \\
\hline \multirow{3}{*}{$\begin{array}{l}\text { Орогены } \\
\text { с практически } \\
\text { сплошнылм распро- } \\
\text { странением } \\
\text { ММП, } \\
\text { мощностью } \\
200-400 \text { м } \\
t^{*}=-3 /-5{ }^{\circ} \mathrm{C} \\
\text { Orogen with } \\
\text { continuous permafrost } \\
(90-100 \%) \text {, thickness } \\
200-400 \text { m }\end{array}$} & \multirow{3}{*}{$\begin{array}{l}\text { Складчатые систе- } \\
\text { мы с сезонным } \\
\text { протаиванием пород } \\
\text { Fold systems with } \\
\text { seasonal thawing } \\
\text { rocks }\end{array}$} & \begin{tabular}{|l} 
Высокогорная \\
Восточно- \\
Саянская \\
High mountains of \\
West Sayan \\
\end{tabular} & $\begin{array}{l}\text { Хр. Шайдын -Ша, } \\
\text { Shayjdyn }\end{array}$ & $2100-2600$ & $1000-1200$ & $\begin{array}{l}\text { Рифей-венд-среднекембрийские образования. Моласса, про- } \\
\text { рванная многочисленными интрузиями } \\
\text { Riphean-Vendian-Cambrian formation. Molasses, broken by } \\
\text { numerous intrusions }\end{array}$ & \multirow{3}{*}{$\begin{array}{l}\text { Землетрясения, ледниковая } \\
\text { эрозия, лавины, сели, об- } \\
\text { вально-осыпные, криоген- } \\
\text { ные, заболачивание плоских } \\
\text { водоразделов } \\
\text { Earthquakes, glacial erosion, } \\
\text { avalanches, mudslides, } \\
\text { landslide, cryogenic, swamping } \\
\text { of flat watersheds }\end{array}$} \\
\hline & & $\begin{array}{l}\text { Высокогорная } \\
\text { Западн-Саянская } \\
\text { High mountains of } \\
\text { West Sayan }\end{array}$ & \begin{tabular}{|l|} 
Хр. Ергаки - \\
Еp/Еrgaki, \\
Хp. Ойский/Oyskiy \\
Хр. Саянский - \\
Са Sауаnskiy \\
Хр. Куртушибин- \\
ский - \\
Кш'/Kurtushiba \\
\end{tabular} & $\begin{array}{l}2000-2460 \\
2300-2825 \\
2200-2400\end{array}$ & $1000-1200$ & $\begin{array}{l}\text { Венд-кембрийские метаморфические сланцы и граниты } \\
\text { Vendian-Cambrian metamorphic schists and granites }\end{array}$ & \\
\hline & & $\begin{array}{l}\text { Высокогорная } \\
\text { Восточно- } \\
\text { Tывинская } \\
\text { High mountains of } \\
\text { East Tuva } \\
\end{array}$ & $\begin{array}{l}\text { Хр. ак. Обручева - } \\
\text { Oб, } \\
\text { Obrucheva }\end{array}$ & $2500-2700$ & $480-600$ & $\begin{array}{l}\text { Докембрийские кристаллические сланцы и гнейсы в основании, } \\
\text { выше - метаморфические сланцы, мраморы, песчаники, из- } \\
\text { вестняки, изверженные породы } \\
\text { Precambrian crystalline schists and gneiss at the base, metamorphic } \\
\text { schists, marbles, sandstones, limestones, igneous rocks - above }\end{array}$ & \\
\hline \multirow{2}{*}{$\begin{array}{l}\text { Ороген } \\
\text { с прерысистыцм } \\
\text { распространением } \\
\text { ММП } \\
\text { мощностью } \\
100-200 \mathrm{M} \\
\mathrm{t}=0 /-2{ }^{\circ} \mathrm{C} \\
\text { Orogen with } \\
\text { discontinuous } \\
\text { permafrost }(50-90 \%), \\
\text { thickness } 120-200 \mathrm{~m}\end{array}$} & \multirow[t]{2}{*}{$\begin{array}{l}\text { Складчатые систе- } \\
\text { мы с сезонным } \\
\text { протаиванием пород } \\
\text { Fold systems with } \\
\text { seasonal thawing } \\
\text { rocks }\end{array}$} & $\begin{array}{l}\text { Сисимо- Казыр- } \\
\text { ская } \\
\text { Sisimo- } \\
\text { Kazyrskaya }\end{array}$ & $\begin{array}{l}\text { Казым-Кизирская } \\
\text { Kazym-Kizirskaya }\end{array}$ & $1500-2000$ & $800-1000$ & $\begin{array}{l}\text { Отложения позднего рифея, венда и кембрия, нарушенные } \\
\text { многочисленными разломами и интрузиями разного возраста. } \\
\text { Преобладает орогенная моласса среднего кембрия (осиновская, } \\
\text { котельская свиты), представленная мусорными конгломерата- } \\
\text { ми, гравелитами, песчаниками с редким присутствием туфов } \\
\text { разного состава } \\
\text { Late Riphean, Vendian and Cambrian sediments disturbed by } \\
\text { numerous faults and intrusions of different ages. The middle } \\
\text { Cambrian orogenic molasse (Osinovskay and Kotel'skaja } \\
\text { formations) dominates. It is presented by garbage conglomerates, } \\
\text { gravelites, sandstones with rare presence of tuffs of different } \\
\text { composition }\end{array}$ & \multirow{2}{*}{$\begin{array}{l}\text { Землетрясения, лавины, } \\
\text { сели, } \\
\text { криогенные: } \\
\text { морозное выветривание, } \\
\text { термокарст, солифлюкция, } \\
\text { наледи; } \\
\text { курумы, } \\
\text { обвалы и осыпи, } \\
\text { карст } \\
\text { Earthquakes, avalanches, } \\
\text { mudflow, } \\
\text { cryogenic: } \\
\text { frost weathering, thermokarst, } \\
\text { solifluction, } \\
\text { icings-aufeis; } \\
\text { stone runs, } \\
\text { landslides and screes, karst }\end{array}$} \\
\hline & & $\begin{array}{l}\text { Северо-Саянская } \\
\text { Northern-Sayan }\end{array}$ & $\begin{array}{l}\text { Северо-Саянская } \\
\text { Northern-Sayan }\end{array}$ & $600-1000$ & $400-500$ & $\begin{array}{l}\text { Породы от нижнего кембрия (нижне-монокская свита: базаль- } \\
\text { ты, андезиты, плагиориты) до среднего кембрия (арбатская } \\
\text { свита: песчаники, конгломераты, линзы известняков) } \\
\text { Rocks from the lower Cambrian (lower-Monokskaya formation: } \\
\text { basalts, andesites, plagionite) to middle Cambrian (Arbatskaja } \\
\text { formation: sandstones, conglomerates, lenses of limestone) }\end{array}$ & \\
\hline
\end{tabular}




\begin{tabular}{|c|c|c|c|c|c|c|c|c|}
\hline & & \multirow{3}{*}{$\begin{array}{l}\text { Центрально- } \\
\text { Западносаянская } \\
\text { Central Western } \\
\text { Sayan }\end{array}$} & $\begin{array}{l}\text { Джебашская } \\
\text { Dzhebash }\end{array}$ & $1000-2000$ & $800-1200$ & $\begin{array}{l}\text { Протерозойские кристаллические сланцы, кембрийские эффу- } \\
\text { зивы, метаморфические сланцы, алевролиты и карбонаты } \\
\text { Proterozoic crystalline schists, Cambrian effusive rocks, } \\
\text { metamorphic shales, siltstones and carbonates }\end{array}$ & & \\
\hline & & & $\begin{array}{l}\text { Центрально- } \\
\text { Западно-саянская } \\
\text { Central Western } \\
\text { Sayan }\end{array}$ & $900-1500$ & $800-1200$ & $\begin{array}{l}\text { Протерозойские кристаллические сланцы, кембрийские эффу- } \\
\text { зивы, метаморфические сланцы, алевролиты и карбонаты пере- } \\
\text { крыты } \\
\text { песчаниками и сланцами ордовика и силура } \\
\text { Proterozoic crystalline schists, Cambrian effusive rocks, } \\
\text { metamorphic shales, siltstones and carbonates are covered with } \\
\text { sandstones and shales of Ordovician and Silurian }\end{array}$ & & \\
\hline & & & $\begin{array}{l}\text { Куртушибинская - } \\
\text { Кш } \\
\text { Kurtushiba }\end{array}$ & $1300-1800$ & $\begin{array}{l}\text { C- } 800-1200 \\
\text { Ю- } 400\end{array}$ & $\begin{array}{l}\text { Офиолитовые венд-кембрийские метатерригенные комплексы } \\
\text { альпинотипных гипербазитов и вулканитов; нижнепалеозой- } \\
\text { ские сланцы, песчаники и известняки, прорванные массивами } \\
\text { гранитоидов раннего девона } \\
\text { Ophiolitic Vendian-Cambrian metaterrigenous complexes of the } \\
\text { Alpine-type ultrabasites and volcanic rocks; lower Paleozoic } \\
\text { schists, sandstones, and limestones, broken massifs of granitoids of } \\
\text { the early Devonian }\end{array}$ & & \\
\hline & & $\begin{array}{l}\text { Западносаянская } \\
\text { Western Sayan }\end{array}$ & $\begin{array}{l}\text { Уюкский хр - } \\
\text { УюХ. } \\
\text { Uyukskiy }\end{array}$ & $1200-1800$ & 330 & $\begin{array}{l}\text { Кембрийские сланцы, песчаники, конгломераты, эффузивы } \\
\text { Cambrian slates, sandstones, conglomerates and volcanites }\end{array}$ & & \\
\hline & & $\begin{array}{l}\text { Таннуольско- } \\
\text { Хамсаринская } \\
\text { Tannuola- } \\
\text { Khamsarinskaya }\end{array}$ & $\begin{array}{l}\text { Восточно- } \\
\text { Таннуольская - } \\
\text { BTo } \\
\text { East Tannuola } \\
\text { Oндумская - Он } \\
\text { Ondum } \\
\end{array}$ & $\begin{array}{l}1500-2000 \\
600-1500\end{array}$ & $\begin{array}{r}\text { C-600-800 } \\
\text { Ю } 200-250\end{array}$ & $\begin{array}{l}\text { Нижнекембрийские вулканогенно-карбонатно-терригенные } \\
\text { породы } \\
\text { Lower Cambrian volcanogenic-carbonate-terrigenous rocks }\end{array}$ & & \\
\hline & & \begin{tabular}{|l|} 
Хемчик- \\
Систигхемская \\
Khemchik- \\
Systygkhem \\
\end{tabular} & \begin{tabular}{|l|} 
Западно- \\
Таннуольская - \\
3Тo \\
Tannuola \\
\end{tabular} & $2500-2700$ & $380-450$ & $\begin{array}{l}\text { Силурские и девонские песчаники, сланцы, конгломераты } \\
\text { Silurian and Devonian sandstones, shales, conglomerates }\end{array}$ & & \\
\hline \multirow{3}{*}{\begin{tabular}{|l} 
Ороген \\
с островным \\
распространением \\
ММП, мощностью \\
$10-30 \mathrm{M}$ \\
$\mathrm{t}=0 /-1,5^{\circ} \mathrm{C}$ \\
Orogen with sporadic \\
permafrost $(<50 \%)$ \\
thickness $10-30 \mathrm{~m}$ \\
\end{tabular}} & \multirow[t]{3}{*}{$\begin{array}{l}\text { Впадины с сезон- } \\
\text { ным протаиванием } \\
\text { пород } \\
\text { Depressions with } \\
\text { seasonal thawing of } \\
\text { rocks }\end{array}$} & $\begin{array}{l}\text { Хемчик- } \\
\text { Систигхемская } \\
\text { Khemchik- } \\
\text { Systygkhem }\end{array}$ & $\begin{array}{l}\text { PZ: Хемчикская - } \\
\text { Хе } \\
\text { Khemchik } \\
\text { Систигхемская - } \\
\text { Cx } \\
\text { Systygkhem } \\
\end{array}$ & $\begin{array}{l}600-1500 \\
650-900\end{array}$ & $500-900$ & $\begin{array}{l}\text { Среднекембрийские-позднекаменноугольные породы, преоб- } \\
\text { ладает ордовик-силурийская моласса } \\
\text { Middle Cambrian - late Carbon rocks, Ordovician-Silurian } \\
\text { molasses dominate }\end{array}$ & \multirow{3}{*}{$\begin{array}{l}\text { Наводнения; криогенные: } \\
\text { морозное выветривание, } \\
\text { повторно-жильные льды, } \\
\text { солифлюкция, каменные } \\
\text { глетчеры; делювиально- } \\
\text { пролювиальные; оврагообра- } \\
\text { зование; эоловые; } \\
\text { засоление } \\
\text { Floods; cryogenic: } \\
\text { frost weathering, ice wedge, } \\
\text { solifluction, rock glaciers; } \\
\text { deluvial-proluvial; gullies; } \\
\text { eolian; } \\
\text { salinization }\end{array}$} & \\
\hline & & \multirow[t]{2}{*}{\begin{tabular}{|l} 
Восточно- \\
Тывинская \\
East Tuva
\end{tabular}} & $\begin{array}{l}\text { PZ: Тоджинская - } \\
\text { Тж } \\
\text { Todzhinskaya }\end{array}$ & $700-800$ & $200-300$ & $\begin{array}{l}\text { Протерозойские и палеозойские породы: песчаники, конгломера- } \\
\text { ты, известняки, кристаллические сланцы, гнейсы, порфириты, } \\
\text { интрузии гранитов и гранодиоритов, перекрыты чехлом морен- } \\
\text { ных и флювиогляциальных четвертичных отложений } \\
\text { Proterozoic and Paleozoic rocks: sandstones, conglomerates, } \\
\text { limestones, crystalline schists, gneiss, porphyrite, intrusions of } \\
\text { granites and granodiorites, covered with a cover of moraine and } \\
\text { fluvioglacial Quaternary sediments. }\end{array}$ & & \\
\hline & & & $\begin{array}{l}\text { PZ: Турано- } \\
\text { Уюкская - ТуУю }\end{array}$ & $800-1200$ & 643-604 & $\begin{array}{l}\text { Терригенные породы ордовика-силура перекрыты нижнедевон- } \\
\text { скими вулканитами кендейской свиты и чехлом моренных и }\end{array}$ & & \\
\hline
\end{tabular}




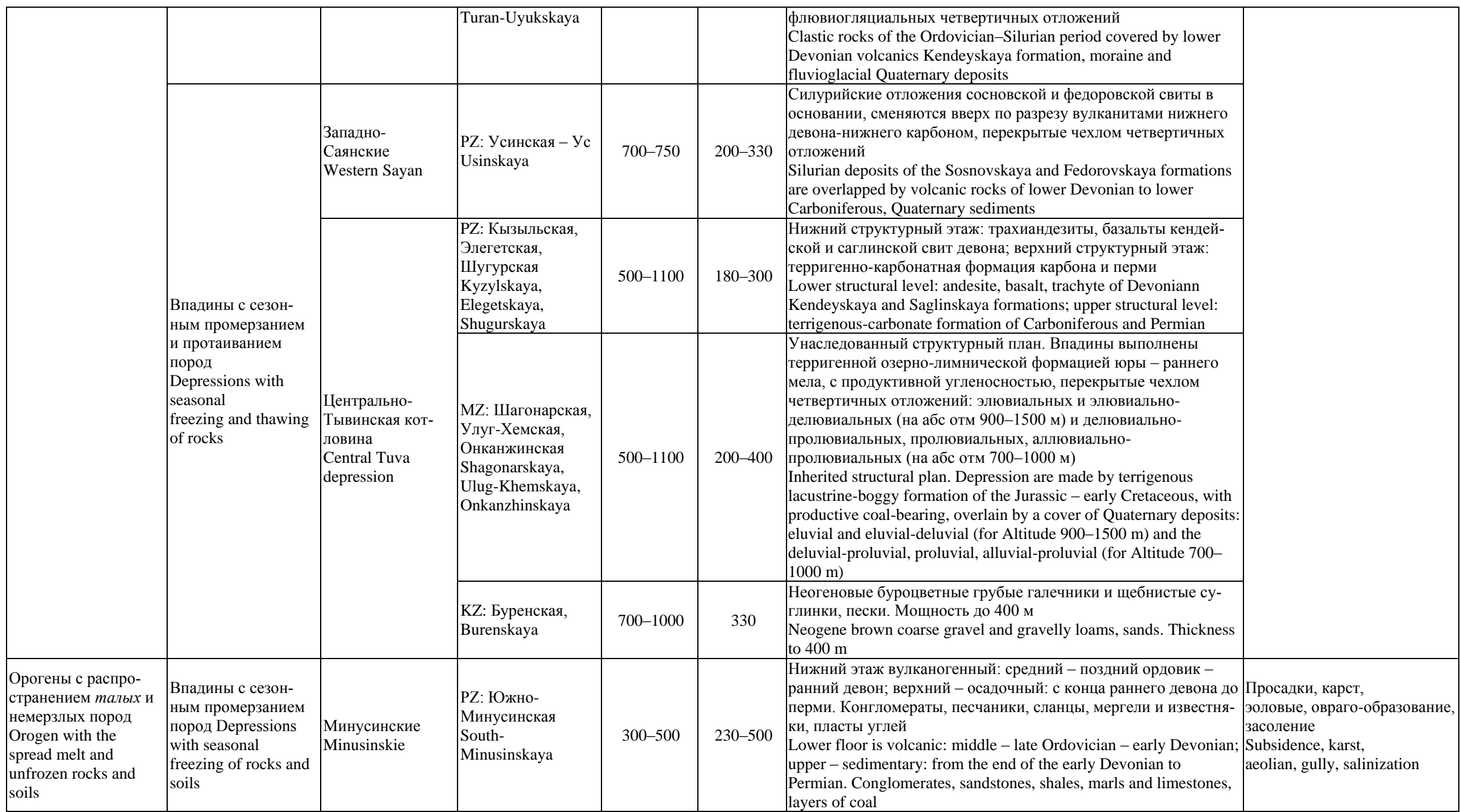

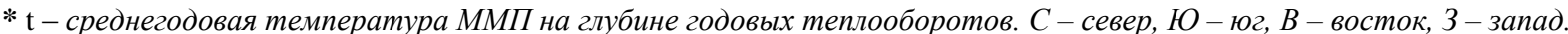

$* \mathrm{t}$ - permafrost temperature - the mean annual ground temperature at the depth of zero annual amplitude (10 to $20 \mathrm{~m})$. C - North, $O$ - South, B - East, 3 - West. 
Следующим этапом работ стала оценка развития геологических процессов и их интенсивности с точки зрения влияния на строительство трассы, с учетом данных [30-35]. Нами разработана классификационная схема опасных геологических процессов с оценкой значимости по шкале баллов, присвоенных экспертно каждому процессу с разбивкой на 2-4 градации (табл. 2).

Таблица 2. Оиенки развития геологических прочессов

Table 2. Assessment of engineering-geological conditions development

\begin{tabular}{|c|c|c|}
\hline $\begin{array}{l}\text { Критерий оценки } \\
\text { Evaluation criterion }\end{array}$ & $\begin{array}{c}\text { Характеристика } \\
\text { Description }\end{array}$ & $\begin{array}{c}\text { Вес критерия в баллах } \\
\text { Criterion weight in points }\end{array}$ \\
\hline \multirow{3}{*}{$\begin{array}{l}\text { Интенсивность неотектонических движений } \\
\text { Intensity of neotectonic movements }\end{array}$} & Слабые/Weak & 0 \\
\hline & Умеренные/Moderate & 1 \\
\hline & Интенсивные/Intensive & 2 \\
\hline \multirow{3}{*}{$\begin{array}{l}\text { Сейсмичность по карте ОСР-2015A, балл } \\
\text { Seismicity by the map OSR-2015A, score }\end{array}$} & 6 & 0 \\
\hline & 7 & 1 \\
\hline & 8 & 2 \\
\hline \multirow{2}{*}{$\begin{array}{l}\text { Распространение просадочных грунтов } \\
\text { Distribution of collapsible soils }\end{array}$} & Не распространены/Not occur & 0 \\
\hline & Распространены/Occur & 1 \\
\hline \multirow{3}{*}{$\begin{array}{l}\text { Распространение карста } \\
\text { Distribution of karst }\end{array}$} & Не распространены/Not occur & 0 \\
\hline & $\begin{array}{l}\text { Распространен карбонатный } \\
\text { Carbonate one is widespread }\end{array}$ & 1 \\
\hline & $\begin{array}{l}\text { Соляной, сульфатно-карбонатный } \\
\text { карст } \\
\text { Salt, sulphate-carbonate karst } \\
\end{array}$ & 2 \\
\hline \multirow{3}{*}{$\begin{array}{l}\text { Распространение оползней } \\
\text { Distribution of landslides }\end{array}$} & $\begin{array}{l}\text { Незначительно-опасные } \\
\text { Slightly dangerous }\end{array}$ & 0 \\
\hline & Малоопасные/Low-risk & 1 \\
\hline & $\begin{array}{l}\text { Умеренно-опасные } \\
\text { Moderately hazardous } \\
\end{array}$ & 2 \\
\hline \multirow{3}{*}{$\begin{array}{l}\text { Распространение селевых явлений } \\
\text { Distribution of mudslides }\end{array}$} & Потенциальная/Potential & 0 \\
\hline & Низкая/Low & 1 \\
\hline & Средняя/Average & 2 \\
\hline \multirow{3}{*}{$\begin{array}{l}\text { Лавиноопасность } \\
\text { Avalanche hazard }\end{array}$} & Низкая/Low & 0 \\
\hline & Средняя/Average & 1 \\
\hline & Высокая/High & 2 \\
\hline \multirow{4}{*}{$\begin{array}{l}\text { Наличие многолетнемерзлых пород } \\
\text { Presence of permafrost }\end{array}$} & Отсутствует/Absent & 0 \\
\hline & Островное/Sporadic & 0,5 \\
\hline & Прерывистое/Discontinuous & 1 \\
\hline & Сплошное/Continuous & 2 \\
\hline
\end{tabular}

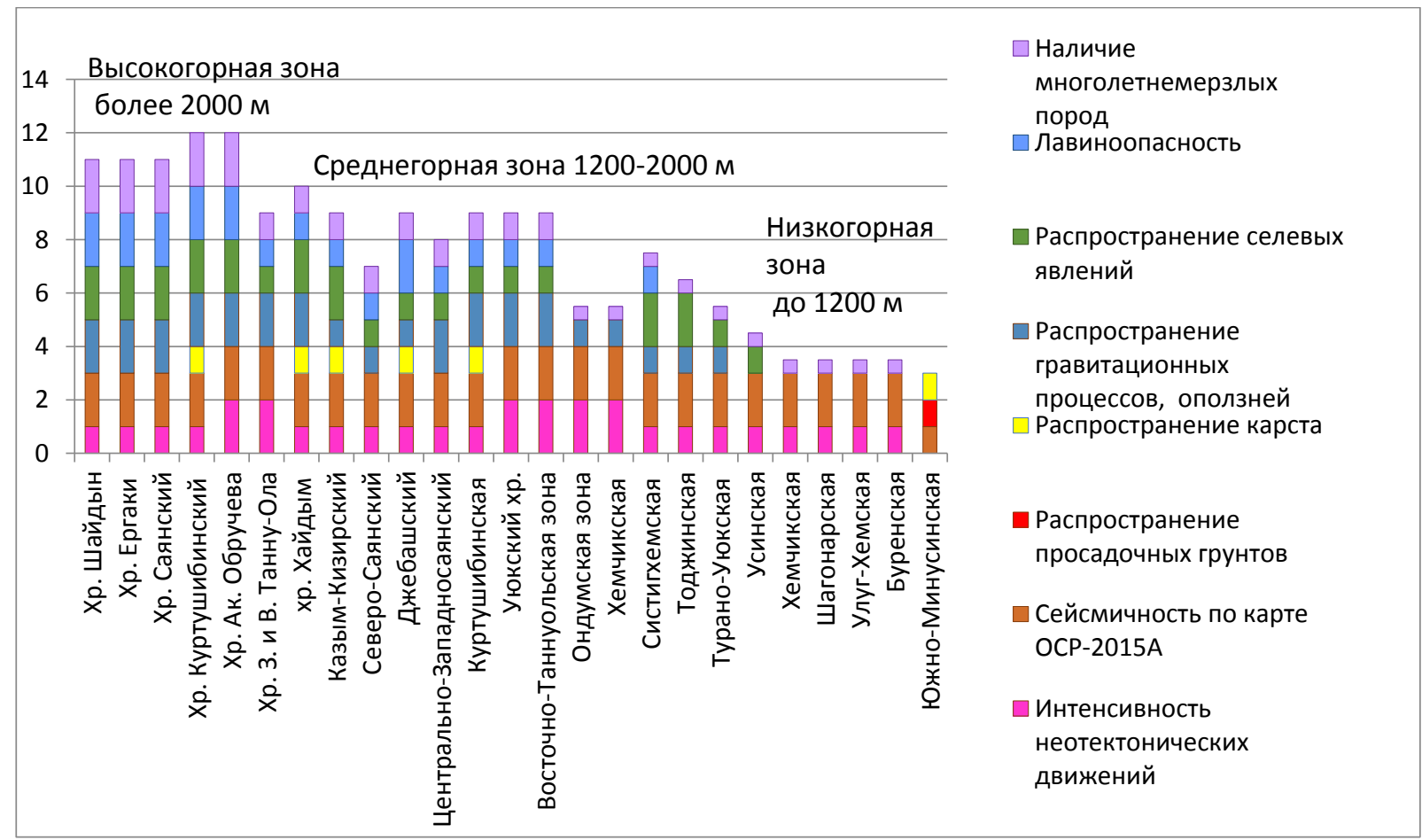

Рис. 4. Балльная оченка инженерно-геологических районов территории

Fig. 4. Scheme of zoning and site assessment 
Обобщенная оценка развития геологических процессов (в баллах) по каждому инженерногеологическому району (структуре III-го порядка), выделенному по регионально-геологическим и зонально-климатическим факторам, приведена на рис. 4.

\section{Обсуждение результатов исследований}

Проведенный анализ литературных и фондовых материалов позволил выбрать классификационные критерии для инженерно-геологического районирования территории трассы. По развитию ММП выделены региональные таксоны I порядка. В пределах структур I порядка по геоструктурным особенностям выделены инженерно-геологические структуры II порядка (мезоструктуры). В пределах последних обособлены и охарактеризованы инженерногеологические структуры III порядка (микроструктуры) по составу горных пород и распространению геологических процессов. Детальная характеристика таксонов III-го порядка приводится впервые для этой территории.

\section{Выводы}

1. Рассмотрение основных природных компонентов территории трассы: сейсмотектоники; литологии; топографии; гидрологии, гидрогеологии и мерзло-

\section{СПИСОК ЛИТЕРАТУРЫ}

1. Andriamamonjisoa S.N., Hubert-Ferrari A. Combining geology, geomorphology and geotechnical data for a safer urban extension: application to the Antananarivo capital city (Madagascar) // Journal of African Earth Sciences. - 2019. - V. 151. - P. 417-437.

2. Baynes F.J., Fookes P.G., Kennedy J.F. The total engineering geology approach applied to railways in the Pilbara, Western Australia // Bulletin of Engineering Geology and the Environment. - 2005. - V. 64. - № 1. - P. 67-94.

3. The interplay of structural pathway and weathering intensity in forming mass-wasting processes in deeply weathered gneissic rocks (Sila Massif, Calabria, Italy) / D. Biondino, L. Borrelli, S. Critelli, F. Muto, G. Gullà // Journal of Maps. - 2018. V. 14. - № 2. - P. 242-256.

4. Cheskidov V.V., Manevich A.I. Engineering and geological support for slope stability monitoring as a part of transport infrastructure construction projects // Mining science and technology. - 2016. - № 1. - P. 50-57.

5. Failache M.F., Zuquette L.V. Geological and geotechnical land zoning for potential Hortonian overland flow in a basin in southern Brazil // Engineering Geology. - 2018. - V. 246. - P. 107-122.

6. Engineering geological mapping of earthquake-induced landslides in South Lefkada Island, Greece: evaluation of the type and characteristics of the slope failures / N. Grendas, V. Marinos, G. Papathanassiou, A. Ganas, S. Valkaniotis // Environmental Earth Sciences. - 2018. - V. 77. - № 12. - P. 425. URL: https://doi.org/10.1007/s12665-018-7598-9 (дата обращения 11.09.2019).

7. Hassanpour J., Firouzei Y., Hajipour G. A regional-scale engineering geological study for selecting suitable rock masses for constructing unlined oil storage caverns in Southern Zagros, Iran // Bulletin of Engineering Geology and the Environment. - 2019. V. 78. - № 1. - P. 267-280.

8. Hearn G.J. Geomorphology in engineering geological mapping and modelling // Bulletin of Engineering Geology and the Environment. - 2019. - V. 78. - № 2. - P. 723-742.

9. Landslide mapping from aerial photographs using change detection-based Markov random field / Z. Li, W. Shi, P. Lu, Q. Wang, Z. Miao // Journal Remote Sensing of Environment. 2016. - V. 187. - P. 76-90. ты показало, что в целом инженерногеологические условия трассы являются достаточно сложными в связи с высокой сейсмической активностью района, наличием многолетней мерзлоты и таких геологических процессов, как карст, сели, лавины, поверхностное заболачивание.

2. Наложение информационных слоев о природной среде позволило разработать карту типологического инженерно-геологического районирования. Дана характеристика выделенных таксонов. Карта районирования послужит основой для принятия обоснованных решений при проектировании инженерных сооружений, базой для организации мониторинга, экспертизы.

3. При проектировании трассы следует учесть опыт строительства линии Абакан-Тайшет, а также разработки китайских специалистов по подготовке и осуществлению строительства ЦинхайТибетской железной дороги, самой высокогорной в мире, проходящей по территории с многолетнемерзлыми грунтами.

Исследование выполнено в Томском политехническом университете в рамках программы повыщения конкурентоспособности Томского политехнического университета (средства ВИУ).

10. Martínez-Graña A.M., Goy J.L., Zazo C. Engineering geology maps for planning and manegement of natural parks: "Las Batuecas-Sierra de Francia» and "Quilamas» (Central Spanish System, Salamanca, Spain) // Geosciences. - 2013. - V. 1. P. 46-62.

11. E-Value of Data - the Qatar geologic mapping project / C.L. Meehan, S. Kumar, M.A. Pando, A.G. Mouradian, A.F. Saleh // Geotechnical Special Publication. - 2019. - V. 3. № 14. - P. 12-23.

12. Development of a 3D structural model of a mine by consolidating different data sources / M. Morales, K.K. Panthi, K. Botsialas, K.H. Holmøy // Bulletin of Engineering Geology and the Environment. - 2019. - V. 78. - № 1. - P. 35-53.

13. Privett K.D. The lines of evidence approach to challenges faced in engineering geological practice // Quarterly Journal of Engineering Geology and Hydrogeology. - 2019. - V. 52. - № 2. - P. 141-172.

14. Ullah K.M., Mansourian A. Evaluation of land suitability for urban land-use planning: Case study Dhaka city // Transactions in GIS. - 2016. - V. 20. - № 1. - P. $20-37$.

15. Hazards posed by active major faults along the Golmud-Lhasa railway route, Tibetan Plateau, China / Z. Wu, P.J. Barosh, D. Hu, P. Ye, W. Jiang // Engineering Geology. - 2004. - V. 74. - № 3-4. P. $163-182$.

16. Yang J. Research on the New railway field geological survey system based on mobile GIS // Journal of Railway Engineering Society. - 2019. - V. 36. - № 2. - P. 15-20.

17. Youssef A.M. Landslide susceptibility delineation in the Ar-Rayth area, Jizan, Kingdom of Saudi Arabia, using analytical hierarchy process, frequency ratio, and logistic regression models // Environmental Earth Sciences. - 2015. - V. 73. - № 12. P. $8499-8518$

18. Zuquette L.V., Failache M. Mapping groundwater pollution vulnerability with application in a basin in southern Brazil // Environmental Earth Sciences. - 2018. - V. 77. - № 19. - P. 689. URL: https://doi.org/10.1007/s12665-018-7862-z (дата обращения 11.09.2019).

19. Ломтадзе В.Д. Словарь по инженерной геологии. - СПб: СПбГИ, 1999. -360 с.

20. Трофимов В.Т., Красилова Н.С. Инженерно-геологические карты. - М.: КДУ, Добросвет, 2018. - 383 с.

21. Инженерная геология России. Т. 3. Инженерно-геологические структуры России / В.Т. Трофимов, Т.И. Аверкина, Т.В. Ан- 
дреева, С.Д. Балыкова, А.В. Бершов, Ю.К. Васильчук, Е.О. Головина, А.В. Ершова, Н.С. Красилова, М.Б. Куринов, В.М. Ладыгин, Ю.В. Фролова. - М.: КДУ, 2015. - 710 с.

22. Трофимов В.Т. Зональность инженерно-геологических условий континентов Земли. - М.: Изд-во МГУ, 2002. - 348 с.

23. Строкова Л.А., Ермолаева А.В. Районирование территории по степени опасности оседания земной поверхности при проектировании магистрального газопровода в южной Якутии // Известия Томского политехнического университета. Инжиниринг георесурсов. - 2016. - Т. 327. - № 10. - С. 59-68.

24. Строкова Л.А., Епифанова Е.А., Коржнева Т.Г. Численный анализ поведения основания опоры моста на старой железнодорожной линии // Известия Томского политехнического университета. Инжиниринг георесурсов. - 2017. - Т. 328. - № 5. C. $125-139$.

25. Strokova L.A., Teterin E. A. Identification, diagnosis and ranking of risks of geohazard in pipeline and urbanized territories // IOP Conference Series: Earth and Environmental Science. - 2016. V. 43. $-6 \mathrm{p}$.

26. Purgina D.V., Strokova L.A., Kuzevanov K.I. Modeling of changing hydrogeological conditions during construction of pier foundations on the Kama river bank // IOP Conference Series: Earth and Environmental Science. - 2016. - V. 33. - 6 p.

27. Опыт инженерно-геологического районирования по несущей способности грунтов промплощадки Эльгинского ГОК в Якутии / Л.А. Строкова, С.А. Дмитриева, Н.В. Осьмушкина, А.В. Осьмушкин // Известия Томского политехнического университета. Инжиниринг георесурсов. - 2019. - Т. 330. - № 2. C. $175-185$.

28. Strokova L.A., Ermolaeva A.V., Golubeva V.V. The investigation of dangerous geological processes resulting in land subsidence while designing the main gas pipeline in South Yakutia // IOP Conference Series: Earth and Environmental Science. - 2016. № 43. $-6 \mathrm{p}$.
29. Строкова Л.А., Ермолаева А.В. Природные особенности строительства участка газопровода «Сила Сибири» на участке Чаяндинское нефтегазоконденсатное месторождение - Ленск // Известия Томского политехнического университета. -2015. № 4. - T. 326. - C. 41-55.

30. Государственная геологическая карта Российской Федерации. Масштаб 1:1000000 (третье поколение) / под ред. Б.А. Блюмана. Серия Алтае-Саянская. Лист М-46 - Кызыл. Объяснительная записка. - СПб.: Картографическая фабрика ВСЕГЕИ, 2008. $-349 \mathrm{c}$

31. Государственная геологическая карта Российской Федерации. Масштаб 1:1000000 (третье поколение) / под ред. Е.П. Миронюк. Серия Алтае-Саянская. Лист N-46 - Абакан. Объяснительная записка. - СПб.: Картографическая фабрика ВСЕГЕИ, 2008. $-391 \mathrm{c}$.

32. СП 115.13330.2016. Геофизика опасных природных воздействий. - М.: ФГУП Стандартинформ, 2016. - 49 с.

33. Особенности проявления неблагоприятных природных процессов на территории республики Тыва / А.Д. Абалаков, А.И. Шеховцов, Г.И. Лысанова, Л.С. Новикова // Успехи современного естествознания. - 2016. - № 6. - С. 132-137. URL: http://www.natural-sciences.ru/ru/article/view?id=35980 (дата обращения: 11.05.2019).

34. СП 14.13330.2018. Строительство в сейсмических районах. Актуализированная редакция СНиП II-7-81*. - М.: ФГУП Стандартинформ, 2018. - $122 \mathrm{c}$.

35. Ганова С.Д., Скопинцева О.В., Исаев О.Н. К вопросу исследования состава углеводородных газов угольных пластов и пыли с целью возможного прогнозирования их потенциальной опасности // Известия Томского политехнического университета. Инжиниринг георесурсов. - 2019. - Т. 330. - № 6. C. $109-115$.

Поступила 19.09.2019 г.

\section{Информация об авторах}

Строкова Л.А., доктор геолого-минералогических наук, профессор отделения геологии Инженерной школы природных ресурсов Национального исследовательского Томского политехнического университета.

Надеждина Ю.Ю., аспирант отделения геологии Инженерной школы природных ресурсов Национального исследовательского Томского политехнического университета. 
UDC 624.131

\title{
TYPIFICATION OF ENGINEERING AND GEOLOGICAL CONDITIONS OF THE TERRITORY OF THE ROUTE OF THE PROJECTED RAILWAY ELEGEST-KYZYL-KURAGINO
}

\author{
Lyudmila A. Strokova ${ }^{1}$, \\ sla@tpu.ru
}

\author{
Yulia Yu. Nadezhdina ${ }^{1}$, \\ levak.yuliya@mail.ru \\ 1 National Research Tomsk Polytechnic University,
30, Lenin avenue, Tomsk, 634050, Russia.
}

The study is relevant due to the development of the project of the first railway in Tyva, which should link Tyva with the Krasnoyarsk territory. The route is planned in very difficult engineering-geological conditions. This article presents the typification of engineering and geological conditions of the territory of the route. An engineering-geological evaluation is necessary in order to prepare decision making on land planning and land use of the area but also so that necessary industrial and infrastructure development can be carried out with smaller impacts on breakable environments as well as reducing hazards and damage to constructions with consequent savings to people and property.

This study aims to conduct typological engineering-geological zoning of the region, taking into account the latest work on the study of engineering-geological conditions of the route.

Object of the study is the geological environment of the area of the projected railway Kuragino-Kyzyl. We considered the main natural components, which influence land use planning and development, such as lithology; topography; seismotectonic; geotechnic; hydrologyhydrogeology and permafrost.

Methods: brief review of relevant literature; analysis of information obtained from geological survey company files, the definition of criterions, signs and methods of zoning. All information layers about the natural environment were processed, and then combined to produce a single engineering-geological map of regions.

Results. We selected the classification features of the geological environment of the study area and produced a map of zoning of engineering-geological conditions of the study. Moreover, we gave the characteristics of the selected taxa.

Summary. A brief description of the main factors of the regional engineering-geological situation is given and the results of zoning based on the principle of formation analysis and classification of engineering-geological conditions of the territory are introduced.

\section{Key words:}

Engineering and geological conditions, regional factors, railway, zoning, geological processes.

The research was carried out at Tomsk Polytechnic University within the Program of Tomsk Polytechnic University Competitiveness Enhancement (VIU funds).

\section{REFERENCES}

1. Andriamamonjisoa S.N., Hubert-Ferrari A. Combining geology, geomorphology and geotechnical data for a safer urban extension: application to the Antananarivo capital city (Madagascar). Journal of African Earth Sciences, 2019, vol. 151, pp. 417-437.

2. Baynes F.J., Fookes P.G., Kennedy J.F. The total engineering geology approach applied to railways in the Pilbara, Western Australia. Bulletin of Engineering Geology and the Environment, 2005, vol. 64, no. 1, pp. 67-94.

3. Biondino D., Borrelli L., Critelli S., Muto F., Gullà G. The interplay of structural pathway and weathering intensity in forming mass-wasting processes in deeply weathered gneissic rocks (Sila Massif, Calabria, Italy). Journal of Maps, 2018, vol. 14, no. 2, pp. 242-256.

4. Cheskidov V.V., Manevich A.I. Engineering and geological support for slope stability monitoring as a part of transport infrastructure construction projects. Mining science and technology, 2016, no. 1, pp. 50-57.

5. Failache M.F., Zuquette L.V. Geological and geotechnical land zoning for potential Hortonian overland flow in a basin in southern Brazil. Engineering Geology, 2018, vol. 246, pp. 107-122.

6. Grendas N., Marinos V., Papathanassiou G., Ganas A., Valkaniotis S Engineering geological mapping of earthquake-induced landslides in South Lefkada Island, Greece: evaluation of the type and characteristics of the slope failures. Environmental Earth Sciences, 2018, vol. 77, no. 12, p. 425. Available at: https://doi.org/10.1007/s12665-018-7598-9 (accessed 11 September 2019).
7. Hassanpour J., Firouzei Y., Hajipour G. A regional-scale engineering geological study for selecting suitable rock masses for constructing unlined oil storage caverns in Southern Zagros, Iran. Bulletin of Engineering Geology and the Environment, 2019, vol. 78 , no. 1, pp. 267-280.

8. Hearn G.J. Geomorphology in engineering geological mapping and modelling. Bulletin of Engineering Geology and the Environment, 2019, vol. 78, no. 2, pp. 723-742.

9. Li Z., Shi W., Lu P., Wang Q., Miao Z. Landslide mapping from aerial photographs using change detection-based Markov random field. Journal Remote Sensing of Environment, 2016, vol. 187, pp. $76-90$

10. Martínez-Graña A.M., Goy J.L., Zazo C. Engineering geology maps for planning and manegement of natural parks: «Las Batuecas-Sierra de Francia» and "Quilamas» (Central Spanish System, Salamanca, Spain). Geosciences, 2013, vol. 1, pp. 46-62.

11. Meehan C.L., Kumar S., Pando M.A., Mouradian A.G., Saleh A.F. E-value of data - the Qatar geologic mapping project. Geotechnical Special Publication, 2019, vol. 3, no. 14, pp. 12-23.

12. Morales M., Panthi K.K., Botsialas K., Holmøy K.H. Development of a 3D structural model of a mine by consolidating different data sources. Bulletin of Engineering Geology and the Environment, 2019, vol. 78, no. 1, pp. 35-53.

13. Privett K.D. The lines of evidence approach to challenges faced in engineering geological practice. Quarterly Journal of Engineering Geology and Hydrogeology, 2019, vol. 52, no. 2, pp. 141-172.

14. Ullah K.M., Mansourian A. Evaluation of land suitability for urban land-use planning: Case study Dhaka city. Transactions in GIS, 2016, vol. 20, no. 1, pp. 20-37. 
15. Wu Z., Barosh P.J., Hu D., Ye P., Jiang W. Hazards posed by active major faults along the Golmud-Lhasa railway route, Tibetan Plateau, China. Engineering Geology, 2004, vol. 74, no. 3-4, pp. 163-182.

16. Yang J. Research on the new railway field geological survey system based on mobile GIS. Journal of Railway Engineering Society, 2019, vol. 36, no. 2, pp. 15-20.

17. Youssef A.M. Landslide susceptibility delineation in the Ar-Rayth area, Jizan, Kingdom of Saudi Arabia, using analytical hierarchy process, frequency ratio, and logistic regression models. Environmental Earth Sciences, 2015, vol. 73, no. 12, pp. 84998518.

18. Zuquette L.V., Failache M. Mapping groundwater pollution vulnerability with application in a basin in southern Brazil. Environmental Earth Sciences, 2018, vol. 77, no. 19, p. 689. Available at: https://doi.org/10.1007/s12665-018-7862-z (accessed 11 September 2019).

19. Lomtadze V.D. Slovar po inzhenernoy geologii [Engineering geology dicrionary]. St-Petersburg, SPGI Publ., 1999. 360 p.

20. Trofimov V.T., Krasilova N.S. Inzhenerno-geologicheskie karty [Engineering-geological maps]. Moscow, KDU, Dobrosvet Publ., 2018.383 p.

21. Trofimov V.T., Averkina T.I., Andreeva T.V., Balykova S.D., Bershov A.V., Vasilchuk Yu.K., Golovina E.O., Ershova A.V., Krasilova N.S., Kurinov M.B., Ladygin V.M., Frolova Yu.V. Inzhenernaya geologiya Rossii. T. 3. Inzhenerno-geologicheskie struktury Rossii [Engineering geology of Russia. Vol. 3 . Engineering-geological structures of Russia]. Moscow, KDU Publ., $2015.710 \mathrm{p}$.

22. Trofimov V.T. Zonalnost inzhenerno-geologicheskikh usloviy kontinentov Zemli [Zoning of engineering-geological conditions of the earth's continents]. Moscow, Moscow state University Publ., $2002.348 \mathrm{p}$.

23. Strokova L.A., Ermolaeva A.V. Zoning according to the hazard level of earth surface subsidence when designing the main gas pipeline in south Yakutia. Bulletin of the Tomsk Polytechnic University. Geo Assets Engineering, 2016, vol. 327, no. 10, pp. 59-68. In Rus.

24. Strokova L.A., Epifanova E.A., Korzhneva T.G. Numerica analysis of bridge foundation behaviour on the old railway line Bulletin of the Tomsk Polytechnic University. Geo Assets Engineering, 2017, vol. 328, no. 5, pp. 125-139. In Rus.

25. Strokova L.A., Teterin E. A. Identification, diagnosis and ranking of risks of geohazard in pipeline and urbanized territories. $I O P$ Conference Series: Earth and Environmental Science, 2016, vol. $43,012051$.
26. Purgina D.V., Strokova L.A., Kuzevanov K.I. Modeling of changing hydrogeological conditions during construction of pier foundations on the Kama river bank. IOP Conference Series: Earth and Environmental Science, 2016, vol. 33, 01246.

27. Strokova L.A., Dmitrieva S.A. Osmushkina N.V., Osmushkin A.V. Experience of engineering-geological zoning on bearing capacity of soils of the industrial site of Elga coal-preparation plant in Yakutia. Bulletin of the Tomsk Polytechnic University. Geo Assets Engineering, 2019, vol. 330, no. 2, pp. 175-185. In Rus.

28. Strokova L.A., Ermolaeva A.V., Golubeva V.V. The Investigation of Dangerous Geological Processes Resulting In Land Subsidence While Designing the Main Gas Pipeline in South Yakutia. IOP Conference Series: Earth and Environmental Science, 2016, vol. $43,6 \mathrm{p}$.

29. Strokova L.A., Ermolaeva A.V. Natural features of construction of the main gas pipeline "The Power of Siberia» on a site Chayandinskoye oil and gas field - Lensk. Bulletin of the Tomsk Polytechnic University, 2015, vol. 326, no. 4, pp. 41-55. In Rus.

30. Gosudarstvennaya geologicheskaya karta Rossiyskoy Federatsii. Masshtab 1:1000000. Seriya Altai-Sayan. List M-46 - Kyzyl [The state geological map of the Russian Federation. Scale 1:1000000. Series Altai-Sayan. Sheet M-46 - Kyzyl]. Ed. by B.A. Blyuman. St-Petersburg, Map factory VSEGEI Publ., 2008. 349 p.

31. Gosudarstvennaya geologicheskaya karta Rossiyskoy Federatsii. Masshtab 1:1000000. Seriya Altai-Sayan. List N-46 - Abakan [The state geological map of the Russian Federation. Scale 1:1000000. Series Altai-Sayan. Sheet N-46 - Abakan]. Ed. by E.P. Mironyuk. St-Petersburg, Map factory VSEGEI Publ., 2008. $391 \mathrm{p}$.

32. SP 115.13330.2016. Geofizika opasnykh prirodnykh vozdeystviy [Set of rules: geophysics of natural hazards]. Moscow, Standartinform Publ., 2016. 49 p.

33. Abalakov A.D., Shekhovtsov A.I., Lysanova G.I., Novikova L.S. Peculiarities of manifestation of hazardous natural processes on the territory of the Republic of Tuva. Successes of modern natural sciences, 2016, no 6. pp. 132-137. In Rus. http://www.naturalsciences.ru/ru/article/view?id=35980 (date of access: 11.05 .2019 ).

34. SP 14.13330.2018. Stroitelstvo v seysmicheskikh rayonakh. Aktualizirovannaya redaktsiya SNiP [Set of rules: construction in seismic areas. Updated version of SNiP II-7-81*]. Moscow, Standartinform Publ., 2018. 122 p.

35. Ganova S.D., Skopintseva O.V., Isaev O.N. On the issue of studying the composition of hydrocarbon gases of coals and dust to predict their potential hazard. Bulletin of the Tomsk Polytechnic University. Geo Assets Engineering, 2019, vol. 330, no. 6, pp. 109-115. In Rus.

Received: 19 September 2019.

\section{Information about the authors}

Lyudmila A. Strokova, Dr. Sc., professor, National Research Tomsk Polytechnic University. Yulia Yu. Nadezhdina, postgraduate student, National Research Tomsk Polytechnic University. 